\section{Sumarlangki Sayoo*}

AN IN VITRO COMPARISON OF ANTIMICROBIAL EFFICACY OF TRIPLE ANTIBIOTIC PASTE, CALCIUM HYDROXIDE AND ACACIA NILOTICA (BABBULA) AGAINST ENTEROCOCCUS FAECALIS, STREPTOCOCCUS MUTANS AND CANDIDA ALBICANS AS INTRACANAL MEDICAMENTS.

\section{Shubhashini N.}

Geeta I. B.
Department Of Conservative Dentistry \& Endodontics, Rajarajeswari Dental College \& Hospital, Bengaluru. ${ }^{*}$ Corresponding Author

\title{
Bindu S
}

Department Of Conservative Dentistry \& Endodontics, Rajarajeswari Dental College \& Hospital , Bengaluru.

Department Of Conservative Dentistry \& Endodontics, Rajarajeswari Dental College \& Hospital , Bengaluru.

Department Of Conservative Dentistry \& Endodontics, Rajarajeswari Dental College \& Hospital , Bengaluru.

ABSTRACT Aim: The aim of this study was to compare the antimicrobial efficacy of Triple antibiotic paste (TAP) Calcium hydroxideand Acacia nilotica (A. nilotica) (Babbula) against Enterococcus faecalis (E. faecalis), Streptococcus mutans (S. mutans) and Candida albicans (C. albicans) as intracanal medicaments.

Materials and methods: The triple antibiotic paste mixture of (metronidazole, ciprofloxacin and minocycline), calcium hydroxide, Acacia nilotica (Babbula) were weighed and mixed with polyethylene glycol and agar well diffusion method was employed to study the antimicrobial efficiency against Enterococcus faecalis, Streptococcus mutans and Candida albicans Results: All the intracanal medicaments showed zone of inhibition against Enterococcus faecalis, Streptococcus mutans and Candida albicans. Among all intracanal medicaments used in the study Triple antibiotic paste produced maximum zone of inhibition followed by Babbula and least by Calcium hydroxide.

Conclusions: Triple antibiotic paste showed the best antimicrobial efficacy followed by Babbula and least by Calcium hydroxide against Enterococcus faecalis, Streptococcus mutans and Candida albicans. More phytochemical studies need to be done. Further evaluation of concentrated extracts of Acacia nilotica (Babbula) could yield better results.

KEYWORDS : Triple antibiotic paste, calcium hydroxide, Acacia nilotica, intracanal medicaments.

\section{INTRODUCTION}

The main aim of root canal treatment is to completely eradicate the microorganisms from the root canal system. However, the root canal configuration is complex and the bacteria within the canal cannot be complete debrided with mechanical instrumentation alone. (1) Hence, intracanal medicaments are used along with instrumentation in aiding the disinfection of the root canal system. ${ }^{(2)}$

Enterococcus faecalis microorganism is notoriously famous and has been isolated in about $24 \%-77 \%$ cases of failure of root canal therapy. This might be due to the ability of this microorganism to withstand high alkaline environment. It survives deep in the dentinal tubules as biofilm and colonizes the root canal. ${ }^{(3)}$ Candida albicans is another microorganism commonly isolated from failed root canals. It breaks down collagen in dentinal wall for its nutrient supply and colonizes inside the root canal. ${ }^{(4)}$ Streptococcus mutans is a grampositive cocci that are usually found in the mouth, and plays a role in formation of dental caries. The bacterium has a polysaccharide coat (glycocalyx) that allows it to stick to the teeth. It also produces acid from sugar in saliva, and this promotes erosion of tooth enamel. ${ }^{(5)}$ S.mutans invades toward pulp and its presence was elucidate in inflamed root canals. ${ }^{(6)}$

Biomechanical preparation along with chemical agent of root canal reduces the bacterial load but use of intracanal medicaments and its action against bacterial agents is required to increase the sterility/decontamination of root canal."

The benchmark of intracanal medicaments is calcium hydroxide and remains popular till date.$^{(8)}$ It is commonly used as an inter-appointment intracanal dressing due to its good biocompatibility ${ }^{(9)}$ It has wide range of antibacterial activity against the pathogens of the root canal. But it has been found less effective against $E$. faecalis as it has been shown to resist high alkaline $\mathrm{pH}$ during calcium hydroxide dressing. ${ }^{(10)}$ Triple antibiotic paste (TAP), is used which is a combination of ciprofloxacin, metronidazole and minocycline has been proven to be effective intracanal medicament. But, minocycline in TAP cause discoloration. ${ }^{111}$

Herbal agents have been used in dentistry which are since ancient times as phytomedicines. The medicinal properties of natural herbal products are useful and have been effective against various diseases. Acacia nilotica commonly known as Gum Arabic tree and Babul in India is a multipurpose tree. It is widely spread in subtropical and tropical Africa to the middle east and in Asia Pakistan and India. The plant has bright yellow coloured flowers and long grey constricted pods. ${ }^{(12)}$ The use of Acacia nilotica in treatment of a cold, cough, diarrhoea, dysentery, jaundice and skin disorders have been proven. ${ }^{(13-16)}$

The present study aimed to compare the antimicrobial efficacy of Triple antibiotic paste, Calcium hydroxide and Acacia nilotica (Babbula) as intracanal medicaments against Enterococcus faecalis, Streptococcus mutans and Candida albicans species.

\section{MATTERIALS AND METHODS MATERIALS}

Preparation of Triple antibiotic paste - Equal amounts metronidazole, ciprofloxacin and minocycline tablets were crushed in 1:1:1 ratio. This was made in powdered form and weight of $50 \mathrm{mg}$ and $100 \mathrm{mg}$ mixed in with polyethylene glycol to make it in paste form.

Preparation of Calcium hydroxide paste $-50 \mathrm{mg}$ and $100 \mathrm{mg}$ of calcium hydroxide powder were weighed separately and made into paste with polyethylene glycol, inoculated and incubated at $37^{\circ} \mathrm{C}$ for 24 hours.

Preparation of Babbula paste -The bark of Babbula tree (Acacia nilotica) was dried, crushed and made in powdered form. The powder was weighed as $50 \mathrm{mg}$ and $100 \mathrm{mg}$ and mixed it with polyethylene glycol to form a paste. 
METHODS:

Standard strains of Enterrococcus faecalis, Candida albicans and Streptococcus mutans (ATCC 29212) were collected from Rajarajeswari Medical College \& Hospital, Bengaluru. It was cultivated in nutrient broth and incubated at $37^{\circ} \mathrm{C}$ for 24 hours, checked for growth under spectrophotometry. Wells of about 6 $\mathrm{mm}$ diameter were made and the microorganisms were spread on the culture plate. Triple antibiotic paste, calcium hydroxide paste, Babbula paste and normal saline (control) were added to respective wells and plates and incubated for 24 hours at $37^{\circ} \mathrm{C}$ in an incubator. The activity of control group was checked for any zone of inhibition against culture. After incubation period, the plates were checked for zones of inhibition and was recorded in millimeter. The study was performed three times and mean zone of inhibition was recorded in millimeter.

\section{RESULTS}
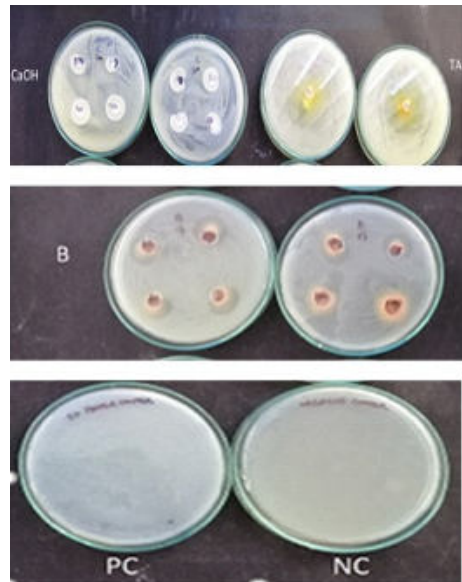

Fig l: Antimicrobial activity against Enterococcus faecalis

*Note: CaOH-Calcium hydroxide, B-Babbula, TA-Triple antibiotic, NS-Normal saline, PC-Positive control, NCNegative control

Table 1: Fig: Antimicrobial activity against Enterococcus farecalis

\begin{tabular}{|l|c|c|}
\hline \multirow{2}{*}{ Sample } & \multicolumn{2}{|l|}{ Diameter of zone of inhibition in $\mathrm{mm}$} \\
\cline { 2 - 3 } & $50 \mathrm{mg}$ & $100 \mathrm{mg}$ \\
\hline Calcium Hydroxide & 15.2 & 15.1 \\
\hline Babbula & 17.8 & 20.1 \\
\hline Triple antibiotic paste & 43.0 & 47.65 \\
\hline
\end{tabular}
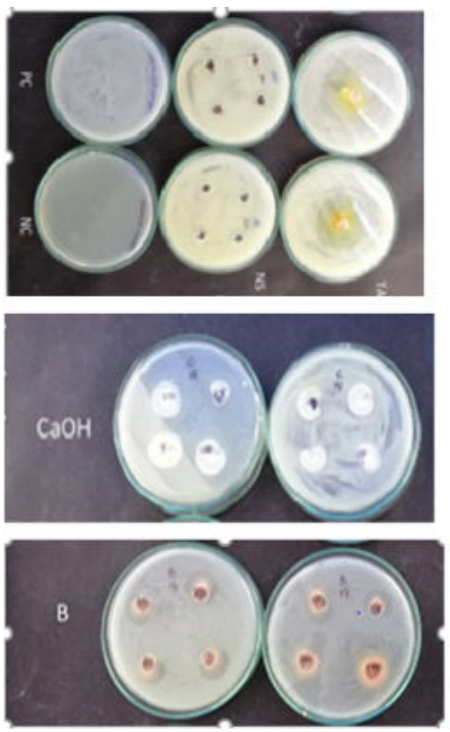

Fig 2: Antimicrobial activity against Streptococcus mutans
*Note: CaOH-Calcium hydroxide, B-Babbula, TA-Triple antibiotic, NS-Normal saline, PC-Positive control, NCnegative control

Table 2: Antimicrobial activity against Streptococcus mutans

\begin{tabular}{|l|c|c|}
\hline Sample & Diameter of zone of inhibition in $\mathrm{mm}$ \\
\hline & $50 \mathrm{mg}$ & $100 \mathrm{mg}$ \\
\hline Calcium Hydroxide & 12.2 & 15.0 \\
\hline Babbula & 19.2 & 19.0 \\
\hline Triple antibiotic paste & 44.6 & 50.2 \\
\hline
\end{tabular}

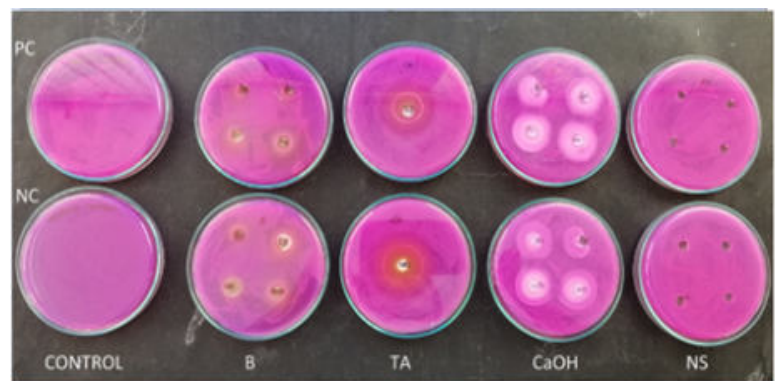

Fig 3: Antimicrobial activity against Candida albicans

*Note: CaOH-Calcium hydroxide, B-Babbula, TA-Triple antibiotic, NS-Normal saline, PC-Positive control, NCnegative control

Table 3: Antimicrobial activity against Candida albicans

\begin{tabular}{|l|l|l|}
\hline \multirow{2}{*}{ Sample } & \multicolumn{2}{|l|}{ Diameter of zone of inhibition in $\mathrm{mm}$} \\
\cline { 2 - 3 } & $50 \mathrm{mg}$ & $100 \mathrm{mg}$ \\
\hline Calcium Hydroxide & 11.8 & 20.2 \\
\hline Babbula & 15.1 & 17.05 \\
\hline Triple antibiotic paste & 35.1 & 45.05 \\
\hline
\end{tabular}

\section{STATISTICAL ANALYSIS}

The results were statistically analysed by one-way ANOVA Test and Tukey's post hoc Analysis test.

Comparison of mean Zone of Inhibition (in mm) for E. Faecalis between Calcium hydrooxide, Babbula \& TAP at 50 \& $100 \mathrm{mg}$ concentrations using One-way ANOVA Test followed by Tukey's Post hoc Analysis

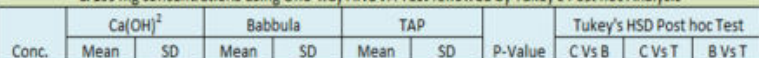

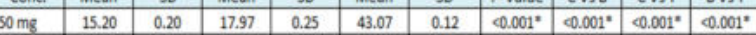
\begin{tabular}{|l|l|l|l|l|l|l|l|l|l|l|}
\hline $100 \mathrm{mg}$ & 15.17 & 0.15 & 20.17 & 0.15 & 47.77 & 0.25 & $<.001^{*}$ & $0.02^{*}$ & $<.001^{*}$ & $<0.001^{*}$ \\
\hline
\end{tabular} Comparison of mean Zone of Inhibition (in mm) for S. Mutans between Calcium hydrooxide, Babbula \& TAP at 50 \& $100 \mathrm{mg}$ concentrations using One-way ANOVA Test followed by Tukey's Post hoc Analysis

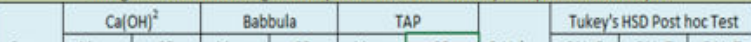

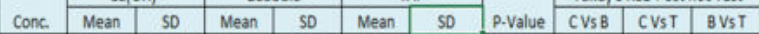
\begin{tabular}{|l|l|l|l|l|l|l|l|l|l|l|}
\hline $50 \mathrm{mg}$ & 12.23 & 0.21 & 19.33 & 0.31 & 44.67 & 0.15 & $0.001^{*}$ & $40.001^{*}$ & $8.001^{*}$ & $\varnothing 0.001^{*}$ \\
\hline
\end{tabular} \begin{tabular}{|c|c|c|c|c|c|c|c|c|c|c|}
\hline $100 \mathrm{mg}$ & 15.07 & 0.12 & 19.07 & 0.12 & 50.20 & 0.20 & $4.001^{*}$ & $\varnothing 0.001^{*}$ & $\$ .001^{*}$ & $\varnothing 0.001^{*}$ \\
\hline \hline
\end{tabular} Comparison of mean Zone of Inhibition (in $\mathrm{mm}$ ) for C. Albicans between Calcium hydrooxide, Babbula \& TAP at 50 \& $100 \mathrm{mg}$ concentrations using One-way ANOVA Test followed by Tukey's Post hoc Analysis \begin{tabular}{|c|c|c|c|c|c|}
\hline & $\mathrm{Ca}(\mathrm{OH})^{2}$ & Babbula & TAP & & Tukey's HSD Post hoc Test \\
\cline { 2 - 3 }
\end{tabular}

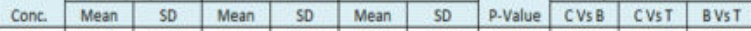
\begin{tabular}{|l|l|l|l|l|l|l|l|l|l|l|}
\hline $50 \mathrm{mg}$ & 11.70 & 0.30 & 15.17 & 0.15 & 35.10 & 0.10 & $0.001^{*}$ & $4.001^{*}$ & $0.001^{*}$ & $0.001^{*}$ \\
\hline
\end{tabular}

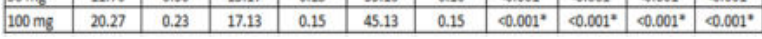

* Statistically significant

Note: C- $\mathrm{Ca}(\mathrm{OH}) 2, \mathrm{~B}-\mathrm{Babbula}, \mathrm{T}-\mathrm{TAP}$

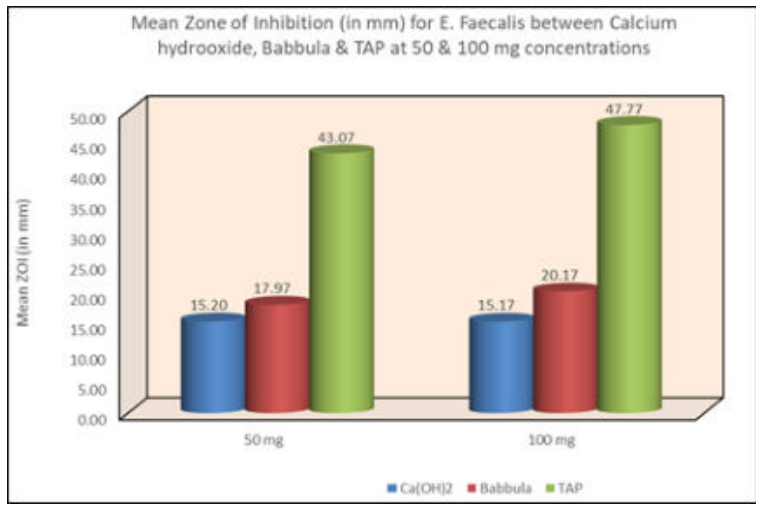



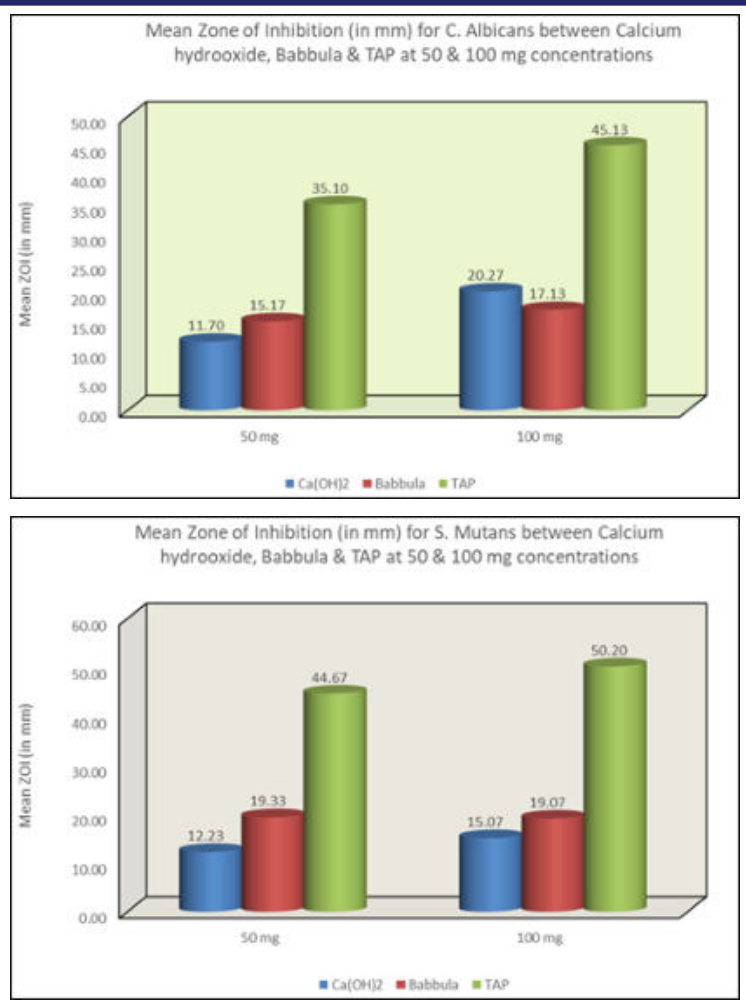

\section{DISCUSSION}

The goal of root canal treatment is to eliminate the primary etiologic agent of endodontic disease i.e. bacteria from the root canal. The microorganisms in root canal are polymicrobial in nature consisting of anaerobic and facultative anaerobic microorganisms. The microorganisms Enterococcus faecalis and Candida albicans are frequently isolated in cases of failed root canal treatment. ${ }^{(17)}$ In cases of failed root-filled teeth which is associated with apical periodontitis, the most frequently isolated organisms are ${ }^{(18)}$ Enterococcus faecalis and Candida albicans are considered to be the most defiance microorganisms in endodontic infections and are implicated as an accessible cause of root canal treatment failure. ${ }^{(19)}$ Both microbes have been detached from infected root canal. ${ }^{(20-24)}$ However, Enterococcus species are shown to be capable of withstanding high $\mathrm{pH}$ changes as well as prolonged periods even with little nutrient supply. ${ }^{(25)}$

Calcium hydroxide is considered the benchmark of intracanal medicaments. It releases hydroxyl ions in a fluidic environment which is responsible for its antimicrobial action. The hydroxyl ions causes damage to the cytoplasm of the bacteria leading to protein denaturation and damage to bacterial DNA. ${ }^{(26)}$

Triple antibiotic paste is a mixture consisting of ciprofloxacin, metronidazole and minocycline. ${ }^{(27)}$ Metronidazole has antibacterial action against anaerobic bacteria. Minocycline has bacteriostatic action on gram-positive and gram-negative bacteria. It also causes an increase in the amount of interleukin-10, which is an inflammatory cytokine. Ciprofloxacin has limited action against anaerobic bacteria while the most susceptible one are the aerobic gram negative bacilli. It acts through the inhibition of DNA gyrase, resulting in degradation of the DNA by exonucleases. It is with metronidazole in the treatment of aerobic and anaerobic infections. ${ }^{(28)}$ Therefore, TAP is effective against wide range of microorganisms i.e. gram-positive, gram-negative and anaerobic bacteria, present in odontogenic infections. ${ }^{(29)}$

Natural products are sometimes considered as alternatives medicines and have been used in India as Ayurveda dating back several thousand years. ${ }^{(30)}$ The World Health Organization (WHO) observed that a great number of herbal extracts are being used in modern medicine. The defence mechanisms present in plants consist of aromatic compounds such as tannins, flavonoids and alkaloids. They help plants in defence against microorganisms, insects and animals in nature. These natural agents present in plants have been isolated for its beneficial properties. Flavonoids present in plants has action on to form a complex with bacterial cell wall and proteins. The antimicrobial activity of phenolic compounds have been shown to be effective in arresting the growth of Candida albicans, Staphylococcus aureus and Staphylococcus epidermidis. Saponins have been shown effective against bacterial and fungal pathogens (Gopishkhanna and Kannabiran, 2008). ${ }^{(31)}$ In the present study, Acacia nilotica was used as it has been shown to possess antibacterial property. Crude alkaloids of Acacia nilotica leaves had higher inhibitory potential against bacterial pathogens such as S. aureus. ${ }^{(32)}$ Deshpande et al. found similar results regarding the effective antimicrobial efficacy of Acacia nilotica against $S$. mutans. ${ }^{(33)}$

The zone of inhibition against $E$. faecalis for $A$. nilotica (Babbula) was $17.8 \mathrm{~mm}$ at $50 \mathrm{mg}$ and $20.1 \mathrm{~mm}$ at $100 \mathrm{mg}$, calcium hydroxide showed result $15.2 \mathrm{~mm}$ at $50 \mathrm{mg}$ and 15.1 $\mathrm{mm}$ at $100 \mathrm{mg}$ and triple antibiotic paste showed result $43 \mathrm{~mm}$ at $50 \mathrm{mg}$ and $47.65 \mathrm{~mm}$ at $100 \mathrm{mg}$ respectively. The zone of inhibition against Streptococcus mutans was A. nilotica (Babbula) showed result $19.2 \mathrm{~mm}$ at $50 \mathrm{mg}$ and $19 \mathrm{~mm}$ at 100 $\mathrm{mg}$, calcium hydroxide showed result $12.2 \mathrm{~mm}$ at $50 \mathrm{mg}$ and 15 $\mathrm{mm}$ at $100 \mathrm{mg}$, and triple antibiotic paste showed result 44.6 $\mathrm{mm}$ at $50 \mathrm{mg}$ and $50.2 \mathrm{~mm}$ at $100 \mathrm{mg}$ respectively. The zone of inhibition against Candida albicans was A. nilotica (Babbula) showed result $15.1 \mathrm{~mm}$ at $50 \mathrm{mg}$ and $17.05 \mathrm{~mm}$ at $100 \mathrm{mg}$, calcium hydroxide showed result $11.8 \mathrm{~mm}$ at $50 \mathrm{mg}$ and 20.2 $\mathrm{mm}$ at $100 \mathrm{mg}$ and triple antibiotic paste showed result 35.1 $\mathrm{mm}$ at $50 \mathrm{mg}$ and $45.05 \mathrm{~mm}$ at $100 \mathrm{mg}$.

Our study demonstrated that A. nilotica (Babbula) has antimicrobial activity against E.faecalis, S.mutans and C.albicans but its potency is better compared to Calcium hydroxide but is less compared to medicaments triple antibiotic paste.

In the present study, Triple antibiotic paste showed maximum zone of inhibition, followed by Babbula and least Calcium hydroxide at $50 \mathrm{mg}$ and $100 \mathrm{mg}$ concentration against E.faecalis, S.mutans and C.albicans Overall, the results of our study showed that triple antibiotic paste was most effective with highest zone of inhibition against E.faecalis, S.mutans and C.albicans

\section{CONCLUSION:}

Triple antibiotic paste showed the best antimicrobial efficacy followed by Babbula and least by Calcium hydroxide against Enterococcus faecalis, Streptococcus mutans and Candida albicans. More phytochemical studies need to be done. Further evaluation of concentrated extracts of Acacia nilotica (Babbula) could yield better results.

\section{REFERENCES}

1. Akpata ES, Blechman H. Bacterial invasion of pulpal dentin wall in vitro. J Dent Res 1982;61:435-8.

2. Byström A, Sundqvist G. Bacteriologic evaluation of the efficacy of mechanical root canal instrumentation in endodontic therapy. European Journal of Oral Sciences. 1981 Aug;89(4):321-8.

3. Wang Z, Shen Y, Haapasalo M. Effectiveness of endodontic disinfecting solutions against young and old Enterococcus faecalis biofilms in dentin canals. J Endod2012;38:1376-9

4. Hagihara Y, Kaminishi H, Cho T, Tanaka M, Kaita H. Degradation of human dentine collagen by an enzyme produced by the yeast Candida albicans. Arch Oral Biol. 1988.

5. Lamont R.J., Demuth D.R., Davis C.A., Malamud D., Rosan B. SalivaryAgglutinin-Mediated Adherence of Streptococcus-Mutans to Early Plaque Bacteria. Infect. Immun. 1991;59:3446-3450. 
6. RyotaNomura, YukoOgaya, Kazuhiko Nakan, Contribution of the CollagenBinding Proteins of Streptococcus mutans to Bacterial Colonization of Inflamed Dental Pulp, DOI:10.1371/journal.pone.0159613 July21,2016

7. Gomes BP, Souza SF, Ferraz CC, Teixeira FB, Zaia AA, Valdrighi L, et al. Effectiveness of $2 \%$ chlorhexidine gel and calcium hydroxide against Enterococcus faecalis in bovine root dentine in vitro. Int Endod J. 2003;36:267-75

8. Mohammadi Z, Dummer PMH. Properties and applications of calcium hydroxide in endodontics and dental traumatology. International Endodontic Journal. 2011.

9. Haapasalo M, Qian W. Irrigants and intracanal medicaments. In: Ingle JI, Bakland LK, Baumgartner JC, editors. Ingle's Endodontics. 6th ed. Hamilton: B.C. Decker Inc.; 2008. p. 100910

10. Siqueira JF, Lopes HP. Mechanisms of antimicrobial activity of calcium hydroxide: A critical review. International Endodontic Journal. 1999.

11. Nakornchai S, Banditsing P, Visetratana N. Clinical evaluation of 3Mix and Vitapex as treatment options for pulpally involved primary molars. Int J Paediatr Dent 2010 May;20(3):214-221

12. M Vijayasanthi , V. Kannan, R. Venkataswamy, A. Doss, Evaluation of the antibacterial potential of various solvent extracts of Acacia niloticalinn leaves, Hygeia.J.D.Med.vol.4 (1), April2012-September2012

13. Kubmarawa D, Ajoku GA, Enwerem NM, Okorie DA. Preliminary phytochemical and antimicrobial screening of 50 medicinal plants from Nigeria. Afr J Biotechnol2007;6:1690-6.

14. Saini ML, Saini R, Roy S, Kumar A. Comparative pharmacognostical and antimicrobial studies of Acacia species (Mimosaceae). J Med Plants Res 2008;2:378-86

15. Pareek A, Trivedi PC. Ethnobotanical studies on medicinal plants of Kaladera region of Jaipur district. Indian J FundamAppl Life Sci 201 1; 1:59-63.

16. Sahu SC, Pattnaik SK, Sahoo SL, Lenka SS, Dhal NK Ethnobotanical study of medicinal plants in the coastal districts of Odisha. Curr Bot 2011;2:17-23.

17. Siqueira JF, Roças IN. Molecular analysis of endodontic infections. Endodontic microbiology Fouad AF Ames: Wiley-Blackwell: 2009. p. 68-107.

18. Haapasalo M, Endal U, Zandi H, Coil J. Eradication of endodontic infection by instrumentation and irrigation solutions, Endod Top 2005; 10:17-102.

19. Roças IN, Siqueira JF, Santos KR. Association of Enterococcus faecalis with different forms or periradicular diseases. J Endod2004;30:315-20

20. Molander A, Reit C, Dahlén G, Kvist T. Microbiological status of root-filled teeth with apical periodontitis. Int Endod J 1998;31:1-7.

21. Hancock HH III, Sigurdsson A, Trope M, Moiseiwitsch J. Bacteria isolated after unsuccessful endodontic treatment in a North American population. Oral Surg Oral Med Oral Pathol Oral RadiolEndod2001;91:579-86.

22. Sundqvist G, Figdor D, Persson S, Sjögren U. Microbiologic analysis of teeth with failed endodontic treatment and the outcome of conservative retreatment. Oral Surg Oral Med Oral Pathol Oral RadiolEndod 1998;85:86-93.

23. Najzer-Felger D, Filipovic G, Prpic G, Kobler D. Candida in root canal in accordance with oral ecology. Int Endod J 1992;25:40-5.

24. Peciuliene V, Balciuniene I, Eriksen HM, Haapasalo M. Isolation of Enterococcus faecalis in previously root-filled canals in a Lithuanian population JEndod 2000;26:593-5.

25. Kaufman B, Spangberg L, Barry J, Fouad AF. Enterococcus spp. in endodontically treated teeth with and without periradicular lesions. J Endod2005;31:851-6.

26. H.K. Haapasalo, E.K. SireA^ n, T.M.T. Waltimo, M.P.P. D. erstavik\&Haapasalo, Inactivation of local root canal medicaments by dentine: an in vitro study, Int. Endod. J. 33 (2000) 126-131.

27. Hargreaves KM, Giesler T, Henry M, Wang Y. Regeneration potential of the young permanent tooth: what does the future hold? J Endod 2008;34 (Supplement):S51-S56.

28. Diwan A, Bhagavaldas MC, Bagga V, Shetty A. Multidisciplinary approach in management of a large cystic lesion in anterior maxilla - a case report. J Clin Diagn Res 2015;9:ZD41-ZD43.

29. Bose R, Nummikoski P, Hargreaves K. A retrospective evaluation of radiographic outcomes in immature teeth with necrotic root canal systems treated with regenerative endodontic procedures. JEndod2009;35:1343-1349.

30. P.Garg, S.P. Tyagi, D.J. Sinha, U.P. Singh, V. Malik, E.R. Maccune, Comparison of antimicrobial efficacy of propolis, Morindacitrifolia, Azadirachtaindica, triphala, green tea polyphenols and $5.25 \%$ sodium hypochlorite against Enterococcus faecalis biofim, Saudi Endod. J 4 (2014) 122-127.

31. Gopishkhanna V, Kannabiran K. Antimicrobial activity of saponin fractions of the leaves Gymnemasylvestre and Ecliptaprostrata. World J Microbiol Biotech., 2008; 24: 2737 - 2740 .

32. M.Vijayasanthi, V.Kannan l, R.Venkataswamy, Evaluation of the Antibacterial Potential of various solvent extracts of Acacia niloticalinn. Leaves, A.Doss3, Hygeia.J.D.Med.vol.4 (1), April2012-September2012

33. Deshpande SN Kadam DG. Phytochemical analysis and antibacterial activity of Acacia nilotica against Streptococcus mutans.International Journal of Pharmacy and Pharmaceutical Sciences, 2013;5:236-8. 